\title{
Peran Pendidik dalam Upaya Deradikalisasi Paham Keagamaan
}

\author{
Fikriansyah \\ UIN Sunan Kalijaga \\ E-mail: fikri4602@gmail.com
}

\begin{abstract}
The radicalism of religious (Islamic) ideology which continues to spread in every circle must receive more attention by doing efforts both preventive, persuasive, repressive and curative. Efforts to de-radicalization in a persuasive way can be done through education. In the world of education, the central figure is an educator. Educators can provide understanding that can accept any differences that exist in Indonesia. as the core of the elimination of radicalism in the world of education is an educator must have a tolerant and pluralist understanding to be able to become an agent of piece. Using literature studies, and case analysis in the field, this paper will provide an conceptual illustration of how a teacher plays a role in the effort to deradicalize religious ideas.
\end{abstract}

Keywords: radicalism, deradicalisation, pluralism, peace education, tolerance

\begin{abstract}
Abstrak. Radikalisme paham keagamaan (Islam) yang saat ini terus menjalar di setiap kalangan harus mendapat perhatian yang lebih dengan melakukan uapaya-upaya baik preventif, persuasive, represif dan kuratif. Usaha deradikalisasi dengan cara persuasive bias dilakukan dengan melalui jalur pendidikan. Dalam dunia pendidikan yangmenjadi tokoh sentral ialah seorang pendidik. Pendidik dapat memberikan pemahaman yang dapat menerima setiap perbedaan yang ada di Indonesia ini. sebagai inti dari peniadaan paham radikalisme di dunia pendidikan ialah seorang pendidik harus memiliki paham yang toleran dan pluralis untuk bisa menjadi seorang agent of piece. Dengan menggunakan studi literature, dan analisi kasus dilapangan, tulisan ini akan memberikan gambaran secara konseptual bagaimana seorang guru berperan dalam usaha deradikalisasi paham keagamaan.
\end{abstract}

Kata Kunci: radikalisme, deradikalisasi, pluralisme, peace education, toleransi

\section{PENDAHULUAN}

Isu tentang radikalisme agama yang ditujukan pada sekelompok umat Islam di Indonesia bukan lagi menjadi hal yang hanya berada pada tatanan opini. Faktanya, paham radikalisme memang berkembang dan terus meningkat tiap tahunnya. Paham radikalisme yang menjangkit sebagian masyarakat di Indonesia bahkan terjadi dikalangan pelajar dan akademisi. Laporan mengenai radikalisme dan ekstrimisme dari para peneliti juga menunjukkan grafik yang menggambarkan bahwa Indonesia sudah berada pada status "siaga" akan paham radikal tersebut. Survei Kemendigbud menghasilkan lebih dari 7 persen siswa di sekolah memiliki paham radikal. 
Selain itu, pada Juni 2019 Setara Institut juga merilis hasil survei yang dilakukan terhadap 10 Universitas yang terdiri atas Universitas keislaman dan Universitas Umum di Indonesia, survey trsebut menghasilkan sedikitnya mahasiswa yang berada pada kelompok moderat dalam pandangan keagamaan (Setarainstitut.org, 2019). Kedua hasil survei di atas menggambarkan kepada kita bahwa lembaga pendidikan di Indonesia cukup rentan untuk dapat mengadopsi paham radikal yang pada tingkat yang cukup ekstrim mereka meniadakan eksistensi ideologi dan agama diluar yang mereka yakini. Hal ini ditakutkan akan menjadi konflik antar umat beragama pada kemudian hari.

Mengutip laporan LAKIP (Lembaga Kajian Islam dan Perdamaian), memperkuat dugaan radikalisasi telah merambah ke dunia pendidikan. Penelitian yang dilakukan pada siswa SMP dan SMA dikawasan Jabodetabek (Jakarta, Bogor, Depok, Tangerang dan Bekasi) memberikan indikasi tentang aksi-aksi radikal yang mereka dukung dan berani lakukan sebagai bagian dari jihad. Paham radikal tampaknya mendapatkan dukungan yang cukup kuat dari kalangan muda di sekolah tingkat SMP dan SMA. Ketika ditanyakan oleh mereka kepada 100 sekolah di Jabodetabek dengan 590 guru, tentang apakah bersedia terlibat dalam aksi kekerasan, sebanyak 38.9\% mendeukung. Ketika ditanyakan apakah aksi Nurdin M. Top itu dapat dibenarkan, sebanyak $14.2 \%$ siswa membenarkan. Sementara ketika ditanyakan apakah setuju dengan diberlakukannya syariat Islam sebanyak $84.8 \%$ menjawab setuju. Sementara ketika ditanyakan apakah Pancasila masih relevan sebangai dasar negara sebanyak $25.8 \%$ menjawab tidak relevan (Qodir, 2015). Beberapa laporan survey di atas menunjukkan angka yang dapat mendukung asumsi bahwa paham radikalisme di Indonesia cukup mendapat tempat di kalangan pemuda khususnya dilembaga pendidikan pada tingkat SMP dan SMA. Tahun 2016, Irvan Armadi, seorang pemuda berusia 17 tahun yang baru lulus dari bangku sekolah, dengan terobsesi oleh ajaran Abu Bakar Al-Baghdadi (pimpinan ISIS) berani melakukan aksi bunuh diri di sebuah gereja (WelleDeutscheOnline, 2016).

Beberapa ciri paling jelas dari ideologi radikal ialah bersifat totaliter, menggunakan pendekatan literal yang dalam memahami ajaran agama, formalisme agama, Manicheanisme (halalharam), pikiran sempit dan menutup diri dari pengaruh eksternal dan puritan (gerakan pemurnian) (Hilmy, 2013). Beberapa kajian yang dilakukan menunjukkan bahwa pemahaman radikal keagamaan menimbulkan aksi kekerasan dengan alasan jihad membela agama. Para pelaku terorisme sejak peristiwa World Trade Center (WTC) di Amerika Serikat pada 11 September 2001 mengaku aksi yang dilakukannya termasuk sebagai bentuk jihad fi sabilillah (Khamdan, 2015). Namun, apa yang dilakukan para pelaku terorisme ini kontradiktif dengan cita-cita moral ideal Islam untuk membangun dunia tanpa mendiskreditkan orang lain yang memiliki keyakinan, 
kebudayaan dan kebiasaan yang berbeda agar terapai kehidupan yang penuh dengan keadilan, kedamaian, kasih sayang dan keharmonisan(Zuhdi, 2017).

Keadaan di atas sudah sepantasnya untuk ditanggulangi. Berbagai pendekatan dapat dilakukan baik dengan militeristik, seperti yang dilakukan Nigeria, telah mengerahkan kekuatan militer dan meminta bantuan negara lain dalam menghadapi pemberontakan Boko Haram (Khamdan, 2015), di Indonesia, (BNPT) telah dimasukkan dalam strategi kontraterorisme Indonesia, terutama setelah peristiwa Bom Bali tahun 2002 (Istiqomah, 2011). Keagamaan, seperti meluruskan doktrin radikal kepada doktrin keagamaan yang lebih moderat dan toleran serta menjaga keseimbangan antara kajian tekstual dan kontekstual dalam memahami Al-Qur'an (Susanto, 2018). Pendidikan, seperti yang dilakukan oleh banyak ahli pendidikan dan akademisi dengan membuat model baru dalam pendidikan seperti pendidikan multicultural yang dikenalkan oleh James Bank, pendidikan karakter oleh Thomas Lickona, pendidikan Islam berwawasan Rabmatan Lil 'Alamin, Piece Education dan lain sebagainya. Karena salah satu upaya sistematis dan terukur yang dapat dilakukan oleh masyarakat adalah melalui pendidikan (Irham, 2017).

Pada suatu lembaga pendidikan, yang paling menjadi sorotan ialah sosok pendidik. Pendidik bertugas untuk mendesain pembelajaran untuk menyampaikan setiap materi pelajaran kepada peserta didiknya. Pendidik harus dapat membentuk kepribadian peserta didik pada setiap dimensinya. Hal ini seperti yang dituliskan oleh (Maragustam, 2018) hakikat pendidik dalam Islam adalah orang-orang yang bertanggungjawab dalam pengembangan peserta didik dengan mengembangkan seluruh potensinya, baik spiritual, afektif, kognitif, maupun psikomotorik ke arah yang lebih baik secara optimal dan seimbang dengan nilai islam. Yang menjadi perhatian pada pengertian di atas ialah bahwa pendidik diharuskan untuk bisa membentuk kepribadian siswa ke arah yang lebih baik dan seimbang dengan nilai Islam. Seorang pendidik dapat membentuk ideology peserta didiknya yang secara disadari atau tidak, mereka akan menginternalisasikan setiap nilai dan sikap yang disampaikan oleh pendidiknya.

Pendidik sangat berpotensi untuk bisa melakukan usaha deradikalisasi. Posisi pendidik yang cukup sentral dalam berlangsungnya proses pembelajaran, membuat pendidik dapat menjadi agen dalam menebarkan ajaran Islam yang ramah, penuh kasih sayang, toleran dan pluralis. Tulisan ini akan mengulas bagaimana pendidk dapat menjadi agent of peace untuk menebarkan sikap toleran dan anti terhadap radikalisme. 


\section{TEMUAN}

\section{Tinjauan Normatif Faktor-Faktor Penyebab Radikalisme}

Radikalisme berkembang dan mulai muncul di permukaan era pasca-Reformasi, setelah jatuhnya Suharto pada tahun 1998. Pada dasarnya, ideologi radikalisme telah tumbuh di Indonesia dalam gerakan bawah tanah (Haryani, 2018). Pada era pasca Suharto mulai dibukanya ruangruang kebebasan termasuk kebebasan dalam ekspresi keagamaan, pembentukan organisasi atau perkumpulan politik. Dalam situasi seperti ini, berbagai gerakan Islam semakin leluasa memajukan aspirasinya secara terang-terangan, termasuk berbagai aspirasi yang pada masa Suharto di anggap subversif misalnya penegakan syariat Islam yang diperjuangkan oleh beberapa organisasi keagamaan militan. Misalnya HTI senantiasa menyuarakan penegakan syariat Islam (Yono, 2016).

Pembahasan mengenai radikalisme paham keagamaan cukup mendapat perhatian di kalangan akademik, radikalisme diartikan dengan banyak pengertian dari bermacam sudut pandang. Seperti yang ditulis oleh Karwadi (2014) dengan mengutip Yusuf Qardhawi yang menggunakan derivasi al-tatarruf untuk menyebut kata radikal, dan al-tatarruf al-dini untuk istilah radikalisme agama. Kata al-tatarruf berarti berdiri di ujung, jauh dari pertengahan, bisa juga diartikan berlebihan dalam suatu hal. Meskipun pada awalnya kata ini digunakan untuk hal-hal yang bersifat kongkret, seperti berlebihan dalam berdiri, duduk, berjalan dan sebagainya, pada tahap berikutnya penggunaannya diperluas termasuk pada hal-hal yang abstrak seperti berlebihan dalam berpikir, beragama, dan berperilaku.

Dalam sudut padang sosiologis, terma radikalisme sering disamakan dengan fundamentalisme, sebagaimana dikemukakan oleh Martin F. Marty, merupakan reaksi atas modernisme, reaksi atas hadirnya kehidupan yang serba cepat, instan dan ciri lainnya adalah tidak ingin berdialog dengan kenyataan yang hadir di hadapannya. Seorang pemikir Islam Bassam Tibi berpendapat bahwa persoalan ekstrimisme lebih dekat dengan urusan relogio politik (agama) yang tengah melanda dunia termasuk dunia arab pada dan Islam pada umumnya ketimbang teologi persoalan teologi Islam (Qodir, 2015).

Beberapa hal mengenai radikalisme di atas dapat menjadi gambaran bahwa radikalisme atau fundamentalisme tercipta tidak hanya dengan satu alasan melainkan beberapa alasan yang bisa saja saling berkaitan. Fundamentalisme tidak terjadi karena faktor teologi, tapi lebih pada faktor ketidaksiapan individu atau kelompok untuk berdialog dengan perubahan sosial yang terjadi, adanya agenda politik dari berbagai pihak, menjadikan mereka mencari tempat berlindung agar dapat melakukan perlawanan. Agama dapat menjadi hal tempat yang tepat untuk menjadi tempat berlindung mereka. Sehingga kemudian lahirlah bibit-bibit radikalisme keagamaan (Islam) 
yang pada tingkat ekstrim, mereka melegitimasikan aksi kekerasan dengan mengatasnamakan agama (Islam) itu sendiri.

Sejalan dengan keterangan di atas, Frans Magnis Suseno (Suseno, 2007) mengatakan bahwa kekerasan yang dilakukan antar umat beragama disebabkan oleh dua faktor, yaitu faktor internal dan faktor eksternal. Faktor internal berupa ajaran atau pemeluk agama itu sendiri dan yang menjadi faktor eksternal ialah faktor ekonomi, pendidikan, politik dan sosial yang kompleks Senada dengan itu, Ahmad Norma mengatakan penyebab aksi terorisme yaitu: pertama, luasnya jarak sosial yang memisahkan kelompok miskin dan kaya, kelompok terdidik dan terbelakang; kedua, instabilitas kehidupan sosial-ekonomi-politik; dan ketiga, kentalnya tradisi agama berbasis doktrin di kalangan masyarakat awam maupun pemimpin mereka (Permata, 2005). Dalam konteks pendidikan, faktor internal dapat lebih mendominasi faktor terjadinya radikalisme. Kurangnya penyampaian substansi Agama (Islam) yang ramah dalam proses pembelajaran menjadikannya tidak dapat mewujudkan pendidikan yang humanistik (Irham, 2017).

Dapat disimpulkan bahwa radikalime paham keagamaan merupakan sikap yang terjadi karena berbagai faktor, baik sosial, ekonomi, politik maupun agama itu sendiri. Semua itu dapat menjadi penyebab timbulnya gerakan-gerakan sosial yang bisa saja berakar pada individu kemudian tumbuh menjadi komunal. Pendidikan juga dapat menjadi sumber dan media penyebaran paham radikal keagamaan. Desain pembelajaran yang kurang mampu mengakomodir perbedaan merupakan sebuah kegagalan yang dapat berakibat fatal. Melekatnya paham keagamaan yang radikal pada usia sekolah (SMP dan SMA) begitu rentan untuk berevolusi menjadi paham ekstrimisme. Ekstrimisme inilah yang menjadi kekhawatiran setiap orang karena akan memunculkan aksi-aksi yang akan mengganggu stabilitas negara dan agama itu sendiri.

\section{DISKUSI}

\section{Radikalisasi dan Deradikalisasi di Lembaga Pendidikan Islam}

Pendidikan merupakan wahana penting dan media yang efektif untuk mengajarkan norma, mensosialisasikan nilai, dan menanamkan etos kerja dikalangan warga masyarkat. Pendidikan juga dapat menjadikan instrument untuk mentata kepribadian bangsa, dan memperkuat identitas nasional, serta memantapkan jati diri bangsa. Pendidikan dapat menjadi wahana strategis untuk membangun kesadaran kolektif sebagai warga dengan mengukuhkan ikatan-ikatan sosial, tetap menghargai keragaman budaya, ras, suku-bangsa, agama, sehingga dapat memantapkan keutuhan nasional (Musyarrofah, 2018).

Pakar pendidikan meyakini bahwa kurikulum memiliki peran penting dalam membentuk iklim sekolah, kepemimpinan dan kompetensi / profesionalisme guru dalam menyampaikan 
pelajaran. Kurikulum, di satu sisi, akan menunjukkan ke arah mana peserta didik tumbuh dan akan mencapai tujuan mereka di lembaga pendidikan. Di sisi lain, kurikulum juga merupakan standar tindakan harus dilakukan oleh seorang pendidik untuk peserta didik. Karena itu, kurikulum selalu digunakan sebagai pedoman ganda untuk pendidik dan lembaga pendidikan di Indonesia untuk merencanakan dan mengimplementasikan proses belajar mengajar (Zainiyati, 2016).

Secara substansial, kurikulum dapat menjadi acuan dalam mengnternalisasikan sebuah paham keagamaan. Sebuah hasil penelitian oleh Charlene Tan dalam Zainiyati (2016) yang dilakukan di sebuah pesantren di Ngruki, Solo, dan di Pondok Pesantren Tebuireng, Jombang. Di Ngruki, konstruksi kedua kurikulum, tertulis atau disembunyikan, ditujukan untuk mengarahkan siswa untuk menjadi bagian dari gerakan untuk menegakkan agama Islam dan sebagai sistem politik di Indonesia. Di Tebuireng, kedua jenis kurikulum dirancang sebagai dasar untuk menumbuhkan toleransi, moderat, dan kecintaan pada negara dan bangsa

Dua kemungkinanan di atas menjadi gambaran peluang untuk menjadikan lembaga pendidikan sebagai tempat untuk menyampaikan doktrin radikal vis a vis doktrin moderat dan toleran. Maka lembaga pendidikan Islam harus mampu mengedepankan kurikulum yang berorientasi pada penanaman sikap moderasi Islam. Moderasi terhadap pemikiran atau ideologi individu atau kelompok yang telah terpapar paham radikal, dalam bahasa lain mengembalikan pemikiran radikal mereka kepada ideologi yang moderat dikenal dengan istilah deradikalisasi (Musyarrofah, 2018). Dalam usaha deradikalisasi, dibutuhkan wacana-wacana yang dapat mengembalikan bentuk pendidikan Islam yang lebih adaptif dan demokratis.

Salah satu istilah yang cukup popular di Indonesia saat ini, khususnya di dunia keagamaan ialah pluralisme. Secara etimologis, pluralisme berasal dari kata bahasa inggris pluralism, yang artinya theory that there are one or more than two kinds of ultimate reality (McKechnie, 1972). Pluralisme diartikan sebagai doktrin filsafat yang menegaskan bahwa substansi tidak hanya satu (sebagaimana diikuti faham monisme) dan tidak pula dua (sebagaimana diikuti faham dualisme), melainkan beragam dan bervariasi (Siregar, n.d.). Menurut O'Collins Farriga, pluralisme adalah suatu pandangan filosofis yang tidak mau mereduksi segala sesuatu pada satu prinsip terakhir, melainkan menerima adanya keragaman (Fariga, 2001). Pluralisme agama sebagai sebuah doktrin atau keimanan yang menyatakan bahwa pluralitas merupakan pokok pembahasan dalam pembicaraan pluralisme; pembicaraan yang menerobos batas konsep agama yang sudah ada tetapi sekaligus juga memasuki wilayah doktrin atau keimanan (Azizy, 1999). Dalam hal ini kita dapat artikan bahwa pluralisme secara sederhana ialah paham yang menimbulkan sikap menerima, menghargai dan mengakui adanya keragaman dalam pemahaman setiap orang. Maka sikap ini 
dapat menciptakan sikap toleran terhadap orang lain, menganggap kebenaran sebagau sesuatu yang bervariasi dan dapat menghindarkan dari sikap eksklusif.

Pluralisme beserta kajiannya telah muncul pada abad ke-19, seiring dengan berkembangnya studi agama yang dikenal dengan istilah comparative religious (perbandingan agama) (Abdullah, 1999). Menurut Kuntowijoyo dalam Biyanto (2013), pluralisme dapat ditipologikan menjadi dua; pluralisme negatif dan pluralisme positif. Pluralisme negatif digunakan untuk menunjukkan sikap keberagamaan sangat ekstrimdengan mengatakan bahwa beragama yang diibaratkan dengan memakai baju sehingga ia dapat menggantinya kapan pun dikehendaki. Sementara pluralisme positif merupakan sikap keberagamaan yang sangat mengedepankan penghormatan terhadap pendapat, pilihan hidup, dan keyakinan. Plualime positif inilah yang dapat menjadi wacana untuk mereduksi sikap radikalisme keberagamaan.

Pluralisme, sering dikaitkan dengan istilah multikulturalimse. Secara etimologis multikulturalisme dibentuk dari kata multi yang artinya banyak, kultur artinya budaya, dan isme yang bermakna suatu aliran atau paham (Mahfudz, 2006). Tujuan umum pendidikan multikultural, pertama, mengembangkan pemahaman yang mendasar tentang proses menciptakan sistem dan menyediakan pelayan pendidikan yang setara. Kedua, Menghubungkan kurikulum dengan karakter guru, pedagogi, iklim kelas, budaya sekolah dan konteks lingkungan sekolah guna membangun suatu visi "lingkungan sekolah yang setara" (Baharun, 2017). Pada hakikatnya, multikultural juga merupakan paham yang mengedepankan semangat menerima dan menghargai setiap perbedaan kebudayaan, kebiasaan serta keyakinan. Kedua paham di atas, merupakan paham yang dapat mereduksi sikap membenarkan diri sendiri (truth claim) dan menihilkan kebenaran selan pada dirinya baik secara individu maupun komunal. Dua paham ini menjadi penting di dunia Islam, dua paham ini disinyalir akan dapat menjadikan setiap umat Islam yang berwawasan moderat dan cenderung tidak ekstrim.

Kedua paham tersebut penting untuk dikembangkan di Indonesia mengingat Indonesia merupakan negara dengan masyarakatnya yang multi ethnic, dan multi religion. Penerimaan setiap perbedaan merupakan sebuah keniscayaan yang harus ada di benak setiap masyarakat di Indonesia. Sikap inklusiv pada setiap dimensi kehidupan harus selalu dipupuk agar selalu siap untuk mendialogkan setiap perbedaan yang ditemui. Menghindari adanya truth claim merupakan salah satu usaha untuk menghindari adanya konflik antar umat berbudaya dan umat beragama. Paradigma pendidikan multicultural dengan mengedepankan substansi ajaran agama yang toleran dan moderat harus diajarkan di lembaga pendidikan baik umum maupun lembaga yang secara khususbernafaskan keagamaan. 
Islam sendiri, dalam teks-teks keagamaannya, merupakan agama yang menerima setiap perbedaan. Menghargai setiap kemajemukan dan bersedia untuk berdialog dengan masyarakat lain dengan segala yang diyakininya. Dalam hal ini alquran menjelaskan dalam QS. Al-Hujurat: 13 "Hai manusia, sesunggubnya Kami menciptakan kamu dari seorang laki-laki dan seorang perempuan dan menjadikan kamu berbangsa-bangsa dan bersuku-suku supaya kamu saling kenal-mengenal. Sesungguhnya orang yang paling mulia diantara kamu disisi Allah ialah orang yang paling takwa diantara kamu. Sesungguhnya Allah Maha Mengetabui lagi Maha Mengenal."

Mendialogkan setiap perbedaan merupakan usaha yang dapat dilakukan agar dapat menambah pemahaman dan sikap moderasi pada diri setiap manusia apapun agamanya. Islam tidak menginginkan adanya sikap menganggap diri yang paling benar, karena dalam hal kebenaran, Allah lah yang paling menentukan. Nabi Muhammad saw diperintahkan untuk menyebarkan agama (Islam) sebagai agama yang dapat menebarkan kasih sayang pada setiap alam semesta baik manusi, hewan ataupun tumbuh-tumbuhan. Seperti yang dituliskan pada alquran "Dan tiadalah Kami mengutus kamu, melainkan untuk (menjadi) rahmat bagi semesta alam" (QS. AlAnbiya [28]: 107)

\section{Pendidik Dalam Usaha Deradikalisasi Paham keagamaan}

Pada dasarnya, setiap agama mengajarkan umatnya untuk berlaku kasih dan sayang terhadap sesamanya. Pesan mendasar dari setiap agama yang ada di muka bumi adalah hidup secara damai dengan seluruh makhluk ciptaan Tuhan (Zuhdi, 2017). Kurangnya penangkapan pesan kebaikan pada setiap agama ini kerap kali menjadi akar terjadinya konflik keagamaan dimanapun berada. Dalam upaya meminimalisir konflik, maka yang harus dilakukan pertama kali adalah penanaman kesadaran kepada masyarakat akan keragaman (plurality), kesetaraan (equality), kemanusiaan (bumanity), keadilan (justice) dan nilai-nilai demokrasi (democration values) (Yaqin, 2005). Upaya meminimalisir sebuah konflik sudah sewajarnya apabila dilakukan secara sistematis.

Dalam konteks pendidikan, kurikulum secara sistemik merupakan teks yang memegang fungsi sebagai panduan bagi pendidik dalam melaksanakan tugasnya untuk mengembangkan pengetahuan peserta didik. Hanya para guru yang tahu dan dapat mengartikan makna dari kurikulum tersebut. Kurikulum Nasional Indonesia seperti yang tertulis dalam Undang-Undang nomor 20 tahun 2003 menyebutkan "Pendidikan nasional berfungsi mengembangkan kemampuan dan membentuk watak serta peradabanbangsa yang bermartabat dalam rangka mencerdaskan kebidupan bangsa, bertujuan untukberkembangnya potensi peserta didik agar menjadi manusia yang beriman dan bertakwa kepadaTuban Yang Maha Esa, berakblak mulia, sehat, berilmu, cakap, kreatif, mandiri, dan menjadi warganegara yang demokratis serta bertanggung jawab". 
Kenyataan yang terjadi adalah setiap lembaga pendidikan memiliki dua kemunginan yang sama dalam memberikan doktrin kepada peserta didik. Beberapa lembaga pendidikan memainkan peran dalam deradikalisasi dan indoktrinasi pemahaman radikal. Ini dibuktikan dengan munculnya kurikulum yang mengedepankan nasionalisme di antara kaum muda, toleransi terhadap orang lain, dan penghargaan terhadap keragaman. Namun, ditemukan juga sekolah yang cenderung berkontribusi pada penyebaran pemahaman radikal (Zainiyati, 2016). Pondok pesantren Ngruki di Solo menjadi alasan perlu adnya re-edukasi dalam memahami integrasi antara nilai universal Islam dengan kurikulum national di Indonesia.

Re-edukasi dalam memahami Islam, pada awalnya, harus ditujukan kepada para pendidik sehubungan dengan kurikulum yang dirancang oleh pemerintah. Berdasarkan gagasan sosiologi di bidang pendidikan, lembaga pendidikan setidaknya harus memiliki tiga aspek. Pertama adalah nilai-nilai ideologis. Kedua, tujuan lembaga pendidikan. Ketiga, para pendidik yang menjalankan proses seleksi transmisi pengetahuan .(Zainiyati, 2016). Pemahaman pendidik tentang Islam baik secara universal maupun partikular menjadi semacam “juru kunci” berhasilnya usaha deradikalisasi dalam suatu lembaga pendidikan.

Dalam perspektif Islam, pendidik adalah orang yang melakukan kegiatan dalam memberikan pengetahuan, pengalaman, keterampilan, baik dengan tatap muka dengan lisan, tulisan atau bentuk lainnya. Dalam bahasa Arab seperti ustaz, mudaris, mua'llim dan mu'addib. Kata ustaz, jamaknya asatiz, dan asatizah sama dengan al-mu'allim (pengajar) jamaknya ulama, al-mudabbir (megatur, mengurus, memimpin dan merencanakan) dan al-alim (terpelajar, ahli ilmu/profesor). Kata mudarris berarti guru dan muaddib orang yang melatih, memperbaiki, mendisiplinkan, mengambil tindakan dan mendidik (Maragustam, 2018).

Pendidik dalam Islam memiliki persyaratan yang cukup ketat, pendidik harus memiliki sifat zubud, ikhlas dalam bekerja, lemah lembut, sopan dan suka pemaaf, menjadi bapak sebelum dia menjadi guru, mengerti tabiat, kecenderungan, kebiasaan, perasaan dan pikiran peserta didiknya agar tidak salah arah dalam memberikan pendidikan, bersih fisik dan jiwa dari dosa besar dan kesalahan, jauh dari sifat mencari nama, dengki, permusuhan dan sifat tercela lainnya, tetap menekuni dan membahas mata pelajaran yang menjadi tugasnya sehingga menjadi pengajar yang tidak kering (Maragustam, 2018). Al-Absrasyi mengatakan salah satu syarat seorang pendidik ialah harus jauh dari rasa benci dan permusuhan. Seorang pendidik harus dapat memunculkan sikap seorang yang mencintai perdamaian dan perdamaian dapat diwujudkan dengan tenggang rasa dan toleransi.

Pendidik dalam Islam, merupakan seorang yang memiliki banyak tanggung jawab, seperti yang dikemukakan oleh Abdullah Nasih Ulwan dalam bukunya Tarbiyah al-Aulad, Dalam hal ini, 
Abdullah Nashih Ulwan menerangkan bahwa sedikitnya, pendidik memiliki tujuh tugas pokok berikut : pertama, tanggungjawab iman. Pendidik diminta untuk dapat mengikat anak dengan nilainilai keimanan, rukun Islam dan dasar-dasar syariah sejak anak mulai dapat mengerti dan memahami sesuatu. Kedua, tanggungjawab moral. Pendidikan mengenai dasar-dasar moral dan keutamaan perangai, tabiat yang harus dimiliki dan dijadikan kebiasaan oleh anak sejak masa analisa hingga ia menjadi seorang mukallaf, pemuda yang mengarungi lautan kehidupan.

Ketiga, tanggungjawab fisik. Beberapa yang dipikulkan Islam di atas pundak orang tua adalah tangung jawab pendidikan fisik anak. Yang demikian ini agar anak-anak tumbuh dengan kondisi fisik yang kuat dan selamat, sehat, bergairah dan semangat. Keempat, tanggungjawab intelektual. Pembentukan dan pembinaan berfikir anak dengan segala sesuatu yang bermanfaat, ilmu pengetahuan hukum, peradaban ilmiah, modernitas serta kesadaran berfikir dan berbudaya. Kelima, tanggungjawab psikis. Ialah mendidik anak supaya bersifat berani, berterus terang dan merasa sempurna, suka berbuat baik dengan orang lain, menahan diri ketika marah, dan senang kepada seluruh bentuk keutamaan psikis serta moral secara keseluruhan.

Keenam, tanggungjawab sosial. Adalah pendidikan anak sejak kecil agar terbiasa menjalankan adab sosial dan dasar-dasar psikis yang mulia yang bersumber pada akidah islamiyah. Ketujuh, tanggungjawab pendidikan seksual. Bermakna pengajaran dan penyadaran tentang masalah-masalah seksual yang diberikan kepada anak, sejak ia dapat mengerti dengan hal-hal yang berhubungan dengan seks (Ulwan, 1981). Mengajarkan nilai inklusiv dan mereduksi paham ekslusiv merupakan salah satu tanggungjawab soial seorang pendidik.

Nilai-nilai eksklusif tentu tidak diharapkan oleh Islam, karena Islam dalam orientasi dakwahnya senantiasa mengajarkan nilai rahmatan lil alamain, penuh dialog dan meninggikan nilainilai humanis (Musyarrofah, 2018). Tiga hal pokok yang dapat dilakukan pendidik agar mampu menangkap pendidikan Islam yang lebih substantif. Pertama, Menjaga keseimbangan antara kajian tekstual dan kontekstual dalam memahami Al-Qur'an. Kedua, menghindari formalitas keagamaan yang dangkal. Ketiga, beragama dengan hanif (Susanto, 2018).

Para kiai (pendidik) mengajar santri di pesantren dengan berbagai kitab mulai dari aqidah, akhlak, fiqh, tafsir, hadits, sejarah, dan lain sebagainya. Istilah jihad, mati syahid, musuh Islam, kafir dan lain-lain bukanlah istilah yang asing bagi warga pesantren. Jikalau mau mengamalkan jihad dalam arti berperang misalnya, tentulah para kiai yang paling pertama melakukannya karena mereka relatif mendalam pengetahuan agamanya, termasuk dalil-dalil berjihad (Farida, 2015).

Toleransi harus di ajarkan kepada setiap generasi agar dapat merawat kemajemukan di Indonesia agar dapat menjadi kekayaan bukan justru menjadi bencana. Pendidikan merupakan tempat yang cukup representatif untuk dapat menjadi lahan penyebaran pemahaman yang toleran 
dan moderat. Seorang pendidik menjadi subjek yang cukup sentral untuk bisa menjadi agen penyebaran dan pembiasaan sikap toleran dan mencintai perdamaian.

Pendidik sebagai role model bagi peserta didik harus mengembangkan pemahamannya mengenai nilai-nilai universal Islam yang pada dasarnya begitu menerima setiap pluralitas yang ada. Pendidik harus dapat menjadi agen perdamaian (agent of peace) dengan membuat desain pendidikan yang dapat menciptakan peserta didik yang toleran, moderat dan jauh dari pemahaman radikal dalam memahami keagamaan.

Paham radikal keagamaan merupakan hal yang cukup berbahaya dan dapat mengancam keutuhan Negara khususnya di Indonesia. Keragaman budaya, bahasa dan keyakinan merupakan hal yang dapat menjadi kekayaan bagi Indonesia. Kemajemukan harus dipelihara dengan menciptakan semangat kecintaan terhadap negara, toleransi, serta menjunjung tinggi setiap pilihan seseorang karena adanya hak asasi pada setiap manusia.

Deradikalisasi atau usaha untuk mereduksi paham radikal keagamaan yang dapat menjadikan kekacauan di bumi Indonesia dikemudian hari dapat dilakukan dengan berbagai cara dan salah satunya ialah melalui pendidikan. Dalam suatu lembaga pendidikan, yang memiliki peran sentral ialah seorang pendidik. Pendidik dalam Islam merupakan seorang yang memiliki derajat yang cukup tinggi di sisi Allah ataupun di sisi manusia. Pendidik memiliki banyak tanggungjawab mulai dari inteleksual hingga sosial.

Pendidik sebagai teladan dan contoh bagi setiap peserta didiknya harus dapat menebarkan dengan sikap toleransi agar dapat menciptakan generasi yang cinta akan perdamaian (loving of peace). Dan yang menjadi kunci akan ini adalah seorang pendidik harus terus mengembangkan pemahamannya mengenai Islam yang moderat yang sesuai dengan semngat Islam rabmatan lil alamin.

\section{REFERENSI}

Abdullah, A. (1999). Studi Agama: Normativitas atau Historisitas. Yogyakarta: Pustaka Pelajar.

Azizy, A. Q. (1999). Al-Qur`an dan Pluralisme Agama. Profetika Jurnal Studi Islam, 1.

Baharun, H. A. (2017). Pendidikan Multikultural Dalam Menanggulangi Narasi Islamisme Di Indonesia. Jurnal Pendidikan Agama Islam (Journal of Islamic Education Studies).

Biyanto. (2013). Pengalaman Muhammadiyapengalaman Muhammadiyah. Islamica.

Farida, U. . (2015). Liberalisme Pesantren: Melacak Pemikiran dan Gerakan Keagamaan Pesantren di Era Globalisasi. Edukasia: Jurnal Penelitian Pendidikan Islam.

Fariga, G. O. S. E. G. (2001). Kamus Teologi,. Yogyakarta: Kanisius. 
Haryani, D. (2018). Islamic Education in Supporting De-radicalization: Islamic Education in Supporting De-radicalization. Nadwa: Jurnal Pendidikan Islam.

Hilmy, M. (2013). The Politics Of Retaliation:The Backlash of Radical Islamists to Deradicalization Project in Indonesia. Al-Jami'Ah.

Irham. (2017). Islamic Education At Multicultural Schools. Jurnal Pendidikan Islam.

Istiqomah, M. (2011). De-radicalization program in Indonesian prisons: Reformation on the correctional institution. Australian Counter Terrorism Conference.

Karwadi. (2014). Islam, Deradikalisasi Pemahaman Ajaran. Al-Tahrir, 14.

Khamdan, M. (2015). Rethinking Deradikalisasi: Konstruksi Bina Damai Penanganan Terorisme. ADDIN.

Mahfudz, C. (2006). Pendidikan Multikultural. Yogyakarta: Pustaka Pelajar.

Maragustam. (2018). Filsafat Pendidikan Islam (Pascasarja). Yogyakarta.

McKechnie, J. L. (1972). Webster New Universal Unabridged Dictionary. New York: The World Publishing Company.

Musyarrofah, M. (2018). Deradikalisasi Melalui Pendidikan Karakter Berbasis Khazanah Pesantren.. Mudarrisuna.

Permata, A. N. (2005). Agama dan Terorisme. Surakarta: Mup Press.

Qodir, Z. (2015). Radikalisme Agama di Indonsia. Yogyakarta: Pustaka Pelajar.

Setarainstitut.org. Tipologi Keberagamaan Mahasiswa: Survei di 10 Perguruan Tinggi Negeri. , (2019).

Siregar, A. . (n.d.). Kamus Lengkap Indonesia-Inggris.

Sujadi, Eko., Meditamar, Muhd. Odha., Ahmad, Bukhari., Rahayu, Anita. (2018). Pengaruh Konsep Diri dan Locus of Control Terhadap Motivasi Berprestasi. Educational Guidance and Counseling Development Jounal, 1 (1): 32-51. dx.doi.org/10.24014/egcdj.v1i1.4808

Sujadi, Eko Sujadi., Ayumi, Rinda Tri., Indra, Syaiful., Sumarto., MRA, Raja Rahima. (2018). Layanan Konseling Kelompok dengan Menggunakan Pendekatan Cognitive Behavioral untuk Membentuk Internal Locus of Control. Jurnal Fokus Konseling, 2 (2): 176-184. https://doi.org/10.26638/jfk.626.2099

Susanto, N. H. (2018). Menangkal Radikalisme Atas Nama Agama Melalui Pendidikan Islam Substantif. Nadwa : Jurnal Pendidikan Islam.

Suseno, F. M. (2007). Memahami Hubungan Antar Agama di Indonesia. Yogyakarta: elSAQ Press.

Ulwan, A. N. (1981). Pedoman Pendidikan Anak dalam Islam. Bandung: Asy-Syifa.

WelleDeutscheOnline. Penyerang Bunub Diri di Gereja Katolik Medan "Terobsesi" Pimpinan ISIS Al Baghdadi. Medan: , (2016). 
Yaqin, A. (2005). Penidikan Multicultural: Cross Cultural Understanding Untuk Demokrasi dan Keadilan. Yogyakarta: Nuansa Aksara.

Yono. (2016). Menakar Akar-Akar Gerakan Radikalisme Agama Di Indonesia Dan Solusi Pencegahannya. Mizan; Jurnal Ilmu Syariah, FAI Universitas Ibn Khaldun (UIKA) Bogor.

Zainiyati, H. S. (2016). Curriculum, Islamic Understanding And Radical Islamic Movements In Indonesia. Journal Of Indonesian Islam.

Zuhdi, M. H. (2017). Radikalisme Agama Dan Upaya Deradikalisasi Pemahaman Keagamaan. , 217. Akademika. 